\title{
The Influence of Neem Oil and Its Glyceride on the Structure and Characterization of Castor Oil-Based Polyurethane Foam
}

\author{
Yi-Han Liao, You-Lin Su and Yi-Chun Chen *(D) \\ Department of Forestry, National Chung-Hsing University, 145 Xingda Rd., South Dist., \\ Taichung City 402, Taiwan; g108033204@mail.nchu.edu.tw (Y.-H.L.); g107033204@mail.nchu.edu.tw (Y.-L.S.) \\ * Correspondence: chenyc@nchu.edu.tw; Tel.: +886-4-2284-0345-148
}

Citation: Liao, Y.-H.; Su, Y.-L.; Chen, Y.-C. The Influence of Neem Oil and Its Glyceride on the Structure and Characterization of Castor Oil-Based Polyurethane Foam. Polymers 2021, 13, 2020. https://doi.org/10.3390/ polym 13122020

Academic Editor: Mirta I. Aranguren

Received: 15 May 2021

Accepted: 13 June 2021

Published: 21 June 2021

Publisher's Note: MDPI stays neutral with regard to jurisdictional claims in published maps and institutional affiliations.

Copyright: (c) 2021 by the authors. Licensee MDPI, Basel, Switzerland. This article is an open access article distributed under the terms and conditions of the Creative Commons Attribution (CC BY) license (https:/ / creativecommons.org/licenses/by/ $4.0 /)$.

\begin{abstract}
Neem (Azadirachta indica) oil is a non-edible oil that contains azadirachtin, which can be used as a biopesticide. This study synthesizes bio-based polyurethane (PU) foam from neem and castor (Ricinus communis L.) oil at normal temperature and pressure. Neem oil can be reacted to narrow-distribution polyol by transesterification of oil and glycerol. Neem oil glyceride (NOG) can be used as polyol for bio-based PU foams and can be blended with castor oil homogeneously to reduce the cost of production. The composition of polyol was castor oil and 0 to $20 \%$ molar ratios of NOG. Hexamethylene diisocyanate trimer (Desmodur N) was used as isocyanate. The molar ratios of $\mathrm{NCO} / \mathrm{OH}$ were set as 1.0, 1.5 and 2.0. The average hydroxyl contents of castor oil, neem oil and NOG were $2.7 \mathrm{mmol} / \mathrm{g}, 0.1 \mathrm{mmol} / \mathrm{g}$ and $5.1 \mathrm{mmol} / \mathrm{g}$, respectively. The reaction time of bio-based PU foam could be adjusted between 5 to $10 \mathrm{~min}$, which is acceptable for manufacturing. The densities of PU foams were between 49.7 and $116.2 \mathrm{~kg} / \mathrm{m}^{3}$ and decreased with increasing $\mathrm{NCO} / \mathrm{OH}$ and NOG ratios and decreasing neem oil. The ranges of specific compressive strength of foams were from 0.0056 to $0.0795 \mathrm{kPa} \cdot \mathrm{m}^{3} / \mathrm{kg}$. Increasing the NOG and neem oil ratio significantly enhanced the specific compressive strength in the low $\mathrm{NCO} / \mathrm{OH}$ ratio. The solvent resistance and thermogravimetric (TG) results showed that the foams have high water and thermal stability. NOG can help to increase solvent resistance. Adding neem oil reduces the solvent resistance. The results indicated that increasing $\mathrm{NCO} / \mathrm{OH}$ and NOG ratios increases the cross-linking density and hard segment content of PU foams. This investigation demonstrated that castor oil-based PU foams are improved by adding NOG to the polyol mixture. PU foam has excellent properties. Neem oil can be used in manufacturing processes to produce high-performance foams via a green synthesis process.
\end{abstract}

Keywords: bio-based polyols; castor oil; foams; neem oil; polyurethane; transesterification

\section{Introduction}

PU resin has flexibility properties and suits to use as various products [1,2]. These raw materials of commercial PU resins are produced from petroleum. However, petroleum is a limited resource with environmental concerns. Chemicals derived from renewable source have attracted attention. The most widely used renewable source to manufacture raw materials for PU products is vegetable oil, available in abundance [3]. Previous investigations have reported bio-based polyols by derivative various vegetable oils, such as neem, castor, rapeseed and soybean oils to develop bio-based PU foams [3-6]. The plant oils can be divided into food and inedible crops. Edible plant oil is not only high production but also stable supply as a positive aspect. On the other hand, Edible plant oil uses in nonfood applications and would result in harm to food supplies and biodiversity. Nowadays, non-edible plant oil has used as a chemical to replace fossil-based resources [7-10].

Castor oil, extracted from the beans, is a toxic oil, which is no competition with plant oil consumption of food crops. The main components of castor oil is ricinoleic acid (12-hydroxy-9-cis-octadecenoic acid, $\mathrm{C}_{18} \mathrm{H}_{34} \mathrm{O}_{3}$ ), which accounts for ca. $89 \%$ directly as a polyol because of the intrinsic hydroxyl groups [11-13]. Moreover, castor oil-derived 
polyols with high functionalities can help to enhance the compressive strength of the PU foam [14]. The stable supply helps make castor oil a widely used raw material for industrial applications [15]. Neem (Azadirachta indica) oil is also a non-edible oil extracted from seeds. Neem, a Meliaceae family plant, is distributed in tropical countries such as India, Myanmar and Malaysia. In 1959, neem was the only plant that survived the locust infestation in Sudan. Investigation indicated that neem has azadirachtin, which is an active compound against bacteria, fungi and parasites. Therefore, neem products have long been used for herbal medicine, pesticides and antibacterial agents. Unsaturated fatty acids account for about $55 \%$ of the content of neem oil. The fatty acid composition includes oleic acid $(50 \%)$, stearic acid $(30 \%)$, palmitic acid $(12 \%)$, linoleic acid $(5 \%)$ and arachidic acid $(3 \%)$. The fatty acids can be modified by acetylation or transesterification and reacted with isocyanates to produce PU resins [16]. Chaudhari et al. (2013) produced renewable sourcebased PU coatings from polyetheramide prepared from neem oil with cyclohexanone and tetrahydrofuran. The impact resistance, flexibility, adhesive properties and chemical resistance showed excellent performance for PU coatings. The thermal stability of neem oil amide based PU coatings was shown to be better than those of traditional urethane and alkyd coatings [17]. Marathe et al. (2015) modified neem oil into acetylated polyester polyol, which responds with different kinds of isocyanates to prepare PU materials with xylene. The results showed that the corrosion resistance of PU materials improved [18]. Das (2021) prepared neem oil-based PU resins by the alcoholysis-polyesterification process with methanol. The PU resin also has application potential as an anticorrosive coating [19]. Previous studies demonstrated that neem oils have a high potential to replace fossil-based polyols for manufacturing high-performance PU coatings. However, the synthetic route of neem oil-based PU resin use toxic organic solvent. The price of neem oil (ca. 19 USD/L) is much higher than that of castor oil (ca. 7 USD/L) in Taiwan. Furthermore, no studies previous have prepared neem oil as the raw material of PU foam.

This study is the first investigation using neem oil as a bio-based polyol for preparing PU foams, to the authors' best knowledge. Castor oil was used as the main bio-polyol to reduce the cost. NOG was prepared by transesterification of oil and glycerol to introduce the hydroxyl group. This study used castor oil and NOG as polyols to react with isocyanate (Desmodur N) and produce bio-based PU foams. Neem oil also replaced the NOG as a natural modifier for preparing reference PU foam [20]. The previous studies have demonstrated that diisocyanates had acute and chronic toxicities [21,22]. Therefore, an isocyanate trimer was used in this study. The mixture of raw materials was blended and reacted under room temperature directly. The solvent-free synthetic route shows in Figure 1. The hydroxyl groups of castor oil and NOG reacted with NCO groups of Desmodur $\mathrm{N}$ to form a urethane structure. The neem oil-based PU foam was prepared as a reference to compare the results. The optimal condition of PU foams was confirmed from chemical, mechanical and thermal results. 


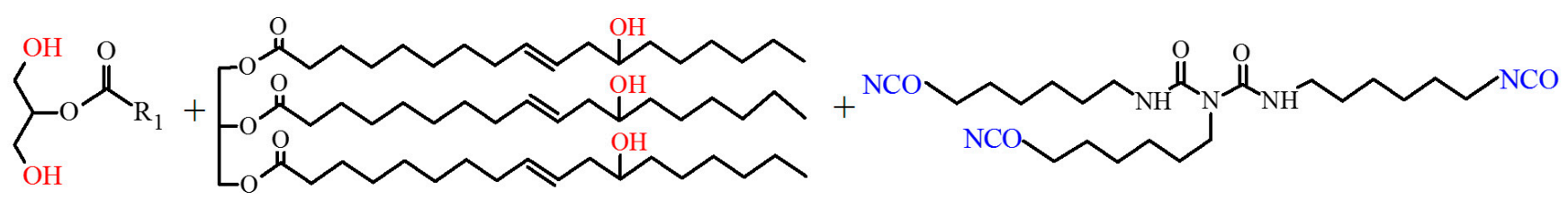

Neem oil Monoglycerides

Castor oil

Desmodur $\mathrm{N}$

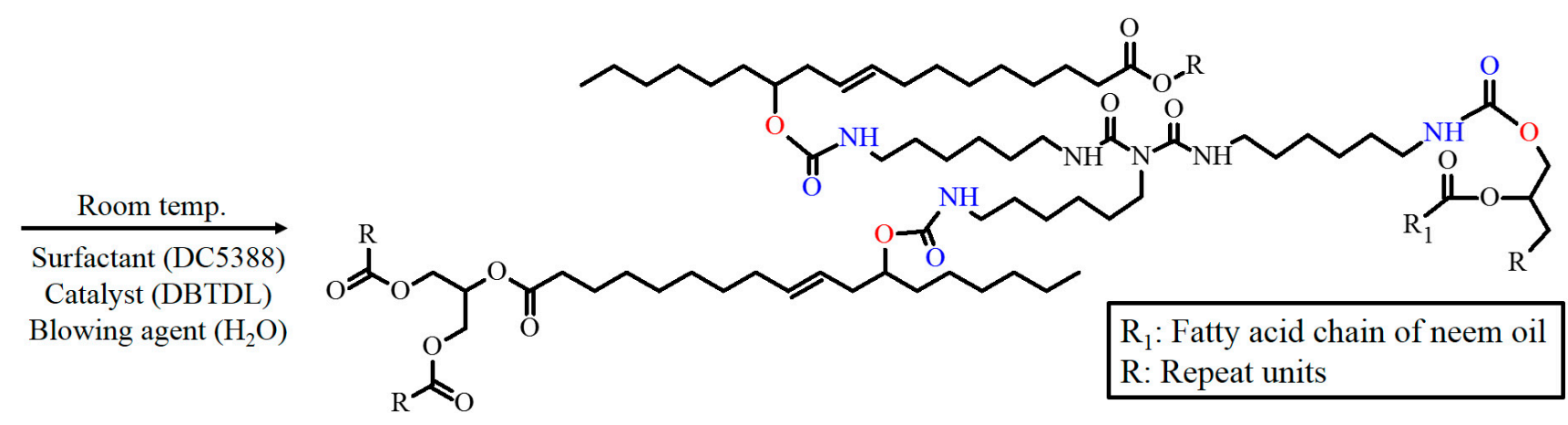

Figure 1. Chemical synthesis route for bio-based PU foam.

\section{Materials and Methods}

\subsection{Materials}

Castor and neem oil were obtained from Chung-Hsing Chemical (Taichung, Taiwan) and Darwin Biotech Co., Ltd (New Taipei City, Taiwan), respectively. Isocyanate Desmodur $\mathrm{N}$ were obtained An Fong Develop Co., Ltd. (Taichung, Taiwan). Desmodur N has a $23.7 \%$ NCO content. The NCO content of isocyanate was determined in the authors laboratory [23]. Organo-siloxane (DC5388, DABCO) and dibutyl tin dilaurate (DBTDL) were purchased from Ya Chung Industrial Co., Ltd. Glycerol and calcium oxide $(\mathrm{CaO})$ were purchased from Union Chemical Works LTD and Sigma Aldrich, respectively.

The method followed by previous study [24]. The transesterification was carried out refluxing glycerol and a $\mathrm{N}_{2}$ gas flow in a four-neck glass flask. Neem oil and glycerol were put in the glass batch reactor. The hydroxyl group molar ratio of neem oil to glycerol was 1: 2 upon stirring. Next, $0.2 \mathrm{wt} \%$ of $\mathrm{CaO}$ (by the weight of oil) was added to the reactants as a catalyst. Reaction time was kept for $3 \mathrm{~h}$ at $220^{\circ} \mathrm{C}$. The transesterification reaction is shown in Figure 2A [24]. 
A<smiles>[R]C(=O)OCC(COC([R7])=O)OC([R])=O</smiles>

Neem oil<smiles>OCC(O)CO</smiles>

Glycerol

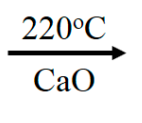

(O)

$\mathrm{OH}$

\section{$\mathrm{R}_{1}$ : Fatty acid chain of neem oil}

B

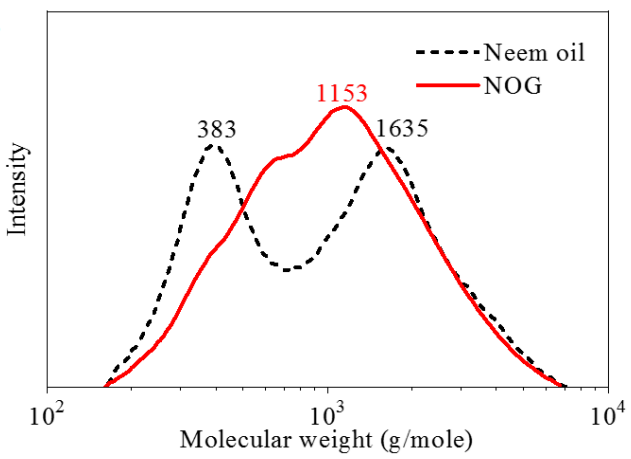

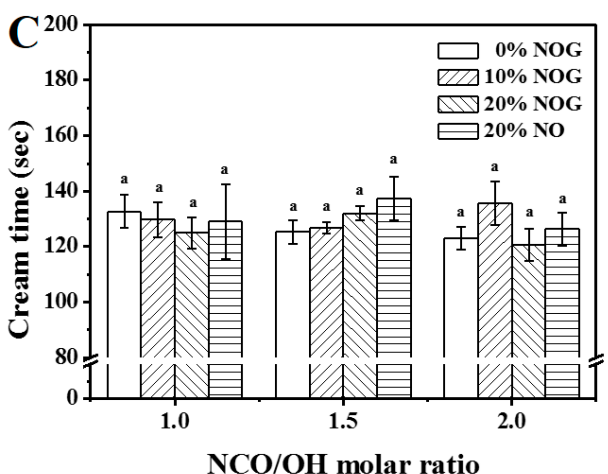
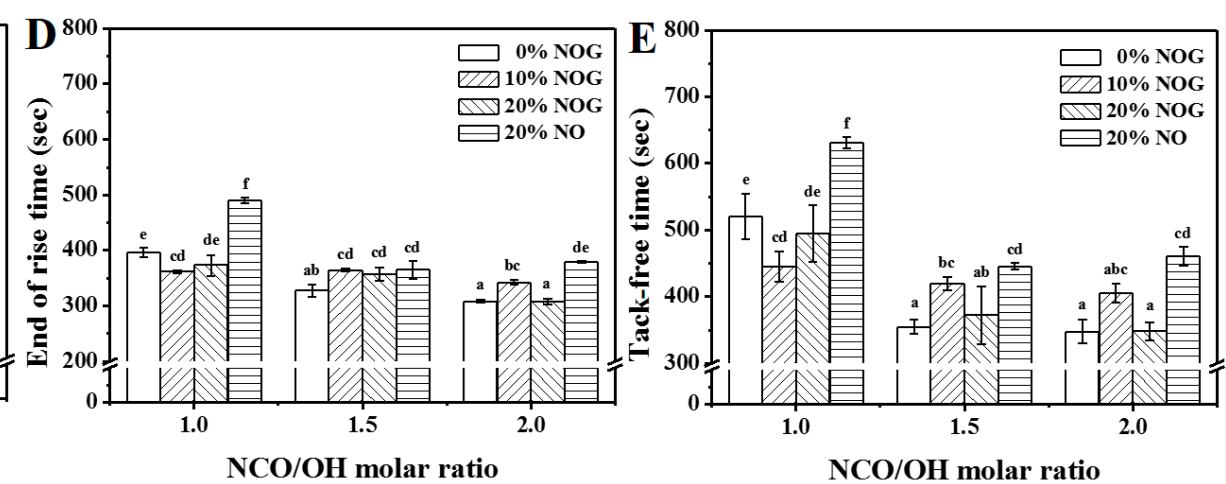

Figure 2. (A) General transesterification scheme of neem oil [14]. (B) Molecular weight distribution of neem oil and NOG. Cream time (C), end of rise time (D) and tack-free time (E) of PU foams. The NCO/OH molar ratios of O1-2, O2-2 and O3-2 set as 1.3, 1.9 and 2.5, respectively. The data analyzed using one-way analysis of variance (ANOVA) with Scheffe's test, the different lowercase letters indicate statistical differences in the bar graph.

\subsection{Basic Properties of Plant Oils and Isocyanate}

Castor oil and Desmodur $\mathrm{N}$ were used as received. The acid value and hydroxyl value of castor oil, neem oil and NOG, and the NCO content of isocyanate were estimated in the authors' laboratory according to previously studied methods [25]. Molecular weight and weight distribution of neem oil and NOG were measured by a Hitachi L-6200A gel permeation chromatographer (Tokyo, Japan). The measurement followed the previous investigation [25]. The average hydroxyl content was calculated as follow [26]:

Average hydroxyl content $(\mathrm{mmol} / \mathrm{g})=$ Hydroxyl value $(\mathrm{mg} \mathrm{KOH} / \mathrm{g}) \div 56.1(\mathrm{~g} / \mathrm{mol})$

\subsection{Preparation of Bio-Based PU Foams}

The PU foams were synthesized from castor oil, neem oil, NOG and Desmodur N. The raw material ratio is shown in Table 1. The hydroxyl molar ratios of castor oil and NOG were set to $10 / 0,9 / 1$ and $8 / 2$. The neem oil was set to $8 / 2$, the same weight as the reference group. $\mathrm{NCO} / \mathrm{OH}$ molar ratios of isocyanate (Desmodur $\mathrm{N}$ ) and the polyol (Castor oil and NOG) were set to 1.0, 1.5, and 2.0. The NCO/OH molar ratios of O1-2, O2-2 and O3-2 set as 1.3, 1.9 and 2.5 because neem oil was used to the same weight as NOG for comparison. The preparation steps of PU foam were as follows: Polyol and isocyanate were mixed in a cup with surfactant (DC5388), blowing agent (distilled water) and catalyst (DBTDL) and then stirred rapidly at $200 \mathrm{rpm}$ for $1 \mathrm{~min}$ at room temperature. Then, the mixture was moved to a mold for casting. The cream time, the end of the rise time, the tack-free time and the height of the mixture were transcribed and determine the rate of reaction. The properties were measured after 1 week at room temperature. 
Table 1. The weight of the raw materials set as to prepare bio-based PU foam.

\begin{tabular}{|c|c|c|c|c|c|c|c|c|}
\hline \multirow{3}{*}{ Code } & \multirow{3}{*}{$\mathrm{NCO} / \mathrm{OH}$} & \multicolumn{7}{|c|}{ Raw Materials (Parts by Weight) } \\
\hline & & \multicolumn{3}{|c|}{ Polyol } & \multirow{2}{*}{ Isocyanate } & \multirow{2}{*}{ Surfactant $^{2}$} & \multirow{2}{*}{ Catalyst $^{2}$} & \multirow{2}{*}{ Blowing Agent ${ }^{2}$} \\
\hline & & Castor Oil & NOG $^{1}$ & Neem Oil & & & & \\
\hline $\mathrm{N} 1-0$ & \multirow{3}{*}{1.0} & 100 & 0 & - & 49 & 4.0 & 4.0 & 4.0 \\
\hline N1-1 & & 100 & 6 & - & 54 & 4.3 & 4.3 & 4.3 \\
\hline N1-2 & & 100 & 13 & - & 61 & 4.5 & 4.5 & 4.5 \\
\hline N2-0 & \multirow{3}{*}{1.5} & 100 & 0 & - & 73 & 4.0 & 4.0 & 4.0 \\
\hline N2-1 & & 100 & 6 & - & 81 & 4.3 & 4.3 & 4.3 \\
\hline N2-2 & & 100 & 13 & - & 92 & 4.5 & 4.5 & 4.5 \\
\hline N3-0 & \multirow{3}{*}{2.0} & 100 & 0 & - & 98 & 4.0 & 4.0 & 4.0 \\
\hline N3-1 & & 100 & 6 & - & 109 & 4.3 & 4.3 & 4.3 \\
\hline N3-2 & & 100 & 13 & - & 122 & 4.5 & 4.5 & 4.5 \\
\hline O1-2 & 1.3 & 100 & - & 13 & 61 & 4.5 & 4.5 & 4.5 \\
\hline O2-2 & 1.9 & 100 & - & 13 & 92 & 4.5 & 4.5 & 4.5 \\
\hline O3-2 & 2.5 & 100 & - & 13 & 122 & 4.5 & 4.5 & 4.5 \\
\hline
\end{tabular}

${ }^{1}$ NOG: Neem oil glyceride. ${ }^{2}$ The addition was based on the total weight of the castor oil, NOG and neem oil.

\subsection{Properties of Neem Oil-Based PU Foams}

\subsubsection{Density}

The density of PU foams were measured according to ASTM D 1622. The density was calculated by the following equation:

$$
\text { Density }\left(\mathrm{kg} / \mathrm{m}^{3}\right)=\text { Specimens' weight }(\mathrm{mg}) \div \text { Specimens' volume }\left(\mathrm{cm}^{3}\right)
$$

Five specimens were determined in this test.

\subsubsection{FTIR}

Fourier-transform infrared analysis (FT-IR, PerkinElmer spectrum 100) was used to confirm the structure of PU foams by the attenuated total reflectance (ATR) method. The analysis was performed within a spectral range of $650-4000 \mathrm{~cm}^{-1}$ at a resolution of $4 \mathrm{~cm}^{-1}$.

\subsubsection{Optical Micrograph}

USB digital microscope (UPMOST/UPG629) was used to observe the images of PU foams. Pore sizes were statistically analyzed by ImageJ. Open cell content was measured from the microscope images. According to previous investigation, the cell window status can be recognized as open, partially open and closed pores. The open content was calculated by the following equation [27]:

$$
\text { Open content }(\%)=(\mathrm{No}+0.5 \mathrm{~Np}) \div(\mathrm{No}+\mathrm{Nc}+\mathrm{Np}) \times 100
$$

where, No, Np and Nc are the numbers of open, partially opened and closed cells. 150 windows of a foam were determined in this test.

\subsubsection{Mechanical Properties}

Following the ASTM C365-00 standard, specimens were cut into $2.54 \times 2.54 \times 1.27 \mathrm{~cm}^{3}$. The mechanical properties of vertical and parallel to the foaming direction were measured using a universal testing machine (Shimadzu EZ -500NSX) with a $5 \mathrm{~mm} / \mathrm{min}$ load speed. The compressive strength corresponds to a stress at $10 \%$ and $25 \%$ strain. Specific compressive strength was calculated according to the following formula:

$$
\text { Specific compressive strength }\left(\mathrm{kPa} \cdot \mathrm{m}^{3} / \mathrm{kg}\right)=\text { Stress }(\mathrm{kPa}) \div \text { Density }\left(\mathrm{kg} / \mathrm{m}^{3}\right)
$$




\subsubsection{Water and Chemicals Resistance}

The method followed by the previous study $[23,25]$. The foam specimens were cut into $1 \times 1 \times 1 \mathrm{~cm}^{3}$ for immersion testing. The solution used distilled water at $25^{\circ} \mathrm{C}$ and $50^{\circ} \mathrm{C}$, and acetone, ethyl acetate and toluene at $25^{\circ} \mathrm{C}$ for $1 \mathrm{~h}$. Five specimens were determined in this test.

\subsubsection{TG Analysis}

TG analysis (TGA, PerkinElmer Pyris 1) set a heating rate of $10{ }^{\circ} \mathrm{C} / \mathrm{min}$ from $50{ }^{\circ} \mathrm{C}$ to $600{ }^{\circ} \mathrm{C}$ in a $\mathrm{N}_{2}$ was carried out to measure the thermal stability of PU foams.

\subsubsection{Statistical Analyses}

We used SPSS (Software version 20, SPSS Inc., Chicago, IL, USA) for statistical analysis. The statistical significance of results was calculated by Scheffe's test. Statistical results mark as English alphabet in the table and the bar graph. The $p$-value was 0.05.

\section{Results and Discussion}

\subsection{Basic Properties of Plant Oils and Isocyanate}

The acid value and hydroxyl value of castor oil, neem oil and NOG are shown in Table 2. The hydroxyl values of castor oil and neem oil are $150.9 \mathrm{mg} \mathrm{KOH} / \mathrm{g}$ and $7.2 \mathrm{mg}$ $\mathrm{KOH} / \mathrm{g}$, respectively. This is because the fatty acid of castor oil has a hydroxyl structure (Ricinoleic acid), while neem oil does not. Castor oil can react with isocyanate and form the urethane bond $[12,23]$. After the transesterification reaction of neem oil, the hydroxyl value of NOG was $281.5 \mathrm{mg} \mathrm{KOH} / \mathrm{g}$, which shows that NOG can also be used as a polyol. Figure $2 \mathrm{~B}$ shows the variations in molecular weight distribution. The molecular weight distribution curves of neem oil and NOG were divided into two and one peaks. The primary fatty acids of neem oil were oleic acid $(50 \%)$, stearic acid $(30 \%)$ and palmitic acid (12\%) [16]. The low molecular weight range may be due to the unsaturated oleic acid reacting with oxygen and then generating oxidation products [28]. Weight average molecular weight $\left(\mathrm{M}_{\mathrm{w}}\right)$, number average molecular weight $\left(\mathrm{M}_{\mathrm{n}}\right)$ and polydispersity of neem oil were $1125 \mathrm{~g} / \mathrm{mol}, 602 \mathrm{~g} / \mathrm{mol}$ and 1.9 , respectively. After transesterification, $\mathrm{M}_{\mathrm{w}}$, $\mathrm{M}_{\mathrm{n}}$, and NOG's polydispersity were $1134 \mathrm{~g} / \mathrm{mol}, 707 \mathrm{~g} / \mathrm{mol}$ and 1.6 , respectively. Low polydispersity of NOG indicated that transesterification can help to narrow the molecular weight distribution of the polyol [29]. From the percentage of molecular weight, the NOG contents of monoglyceride and diglyceride were $68.7 \%$ and $21.6 \%$ respectively [30]. The average hydroxyl contents of castor oil, neem oil and NOG were $2.7 \mathrm{mmol} / \mathrm{g}, 0.1 \mathrm{mmol} / \mathrm{g}$ and $5.1 \mathrm{mmol} / \mathrm{g}$. The results indicated that the average hydroxyl content of NOG was much higher than that of neem oil.

Table 2. The basic properties of castor oil, neem oil and NOG.

\begin{tabular}{ccccccc}
\hline Code & $\begin{array}{c}\text { Acid Value } \\
(\mathbf{m g ~ K O H} / \mathbf{g})\end{array}$ & $\begin{array}{c}\text { Hydroxyl } \\
\text { Value } \\
(\mathbf{m g ~ K O H} / \mathbf{g})\end{array}$ & $\mathbf{M}_{\mathbf{w}}{ }^{\mathbf{2}} \mathbf{( \mathbf { g } / \mathbf { m o l } )}$ & $\begin{array}{c}\mathbf{M}_{\mathbf{n}}{ }^{3} \\
\mathbf{( g / m o l})\end{array}$ & $\begin{array}{c}\text { Polydispersity } \\
\left.\mathbf{( M}_{\mathbf{w}} / \mathbf{M}_{\mathbf{n}}\right)\end{array}$ & $\begin{array}{c}\text { Average Hydroxyl } \\
\mathbf{C o n t e n t}(\mathbf{m m o l} / \mathbf{g})\end{array}$ \\
\hline Castor oil & $2.1 \pm 0.1$ & $150.9 \pm 4.6$ & $1181^{4}$ & 1150 & 1.0 & 2.7 \\
Neem oil $^{\text {NOG }}{ }^{1}$ & $7.2 \pm 0$ & $7.2 \pm 0$ & 1125 & 602 & 1.9 & 0.1 \\
\hline
\end{tabular}

${ }^{1}$ NOG: Neem oil glyceride. ${ }^{2} \mathrm{M}_{\mathrm{w}}$ : Weight average molecular weight. ${ }^{3} \mathrm{M}_{\mathrm{n}}$ : Number average molecular weight. ${ }^{4}$ The data measured by a previous study [31].

\subsection{The Basic Properties and Pore Structure of PU Foams}

The foaming properties of PU foams are shown in Figure 2C-E. With increasing $\mathrm{NCO} / \mathrm{OH}$ ratio, we found a difference in the tack-free time. The tack-free time decreased significantly because of high reactivity between the $\mathrm{OH}$ and $\mathrm{NCO}$ groups. This result is the same as previous study that showed that increasing $\mathrm{NCO} / \mathrm{OH}$ ratio can shorten the foaming reaction time [32]. The results also showed that the end of rise time and tack-free 
time of neem oil-based PU foam were significantly longer than those of castor oil- and NOG-based PU foams. Without a hydroxyl structure, neem oil dilutes the reactants. The reaction time of bio-based PU foam can be adjusted between $5 \mathrm{~min}$ to $10 \mathrm{~min}$, which is acceptable for laboratory and industrial manufacturing processes.

As shown in Figure 3A,B, the volume expansion and densities of PU foams grow up and drop off with an increasing $\mathrm{NCO} / \mathrm{OH}$ ratio, similar to the findings of previous studies [32]. The respective densities of N1-0, N1-1, N1-2, N2-0, N2-1, N2-2, N3-0, N3-1 and, N3-2 are $105.5,102,97.9,91.5,74.1,68.7,81.7,51.0$ and $49.7 \mathrm{~kg} / \mathrm{m}^{3}$. The results, similar to previous studies, show that the increasing $\mathrm{NCO} / \mathrm{OH}$ ratio decreases density [32]. The result also suggests that isocyanate reacts with water to release $\mathrm{CO}_{2}$ for the foaming stage [33] and the reaction generated heat helps expand the cell structure and leads to an increase in the volume expansion of the PU foam. These results also indicate that the density of neem oil-based PU foam is significantly higher than that of NOG-based PU foam. The densities of O1-2, O2-2 and, O3-2 are 116.2, 81.4 and $70.8 \mathrm{~kg} / \mathrm{m}^{3}$, respectively. This result is due to NOG polyol with secondary hydroxyl groups which helps the PU resin to cure rapidly and maintain the foam's structural integrity during the foaming process [34]. Figure 4 displays the PU foam micrographs. The pictures show an open-pore structure and elongated cellular structures in the foam rise direction. The open cell contents of N1-0, N1-1, N1-2, N2-0, N2-1, N2-2, N3-0, N3-1, N3-2, O1-2, O2-2 and O3-2 are $85.9 \%, 87.9 \%, 84.4 \%, 84.5 \%, 82.5 \%, 83.5 \%$, $81.5 \%, 77.7 \%, 83.6 \%, 83.8 \%, 82.0 \%$ and $81.2 \%$. Figure $3 \mathrm{C}$ shows that the range of pore sizes of PU foams is from $588.3 \mu \mathrm{m}$ to $758.0 \mu \mathrm{m}$. The pore size of N3-2 is larger than those of the others significantly. The results indicated that a high $\mathrm{NCO} / \mathrm{OH}$ ratio increases the pore size of $\mathrm{PU}$ foams because isocyanate reacts with water and generated $\mathrm{CO}_{2}$ bubble [33]. On the other hand, even though $\mathrm{NCO} / \mathrm{OH}$ ratio of O1-2, O2-2 and O3-2 is higher than that of N1-2, N2-2 and N3-2, densities and pore sizes of neem oil-based PU foams are more heightened and smaller than those of NOG-based PU foams. These results suggest that neem oil is without a hydroxyl structure and dilutes the reactants to reduce gas production. The morphology also can prove the PU foams are homogenous and successfully prepared.
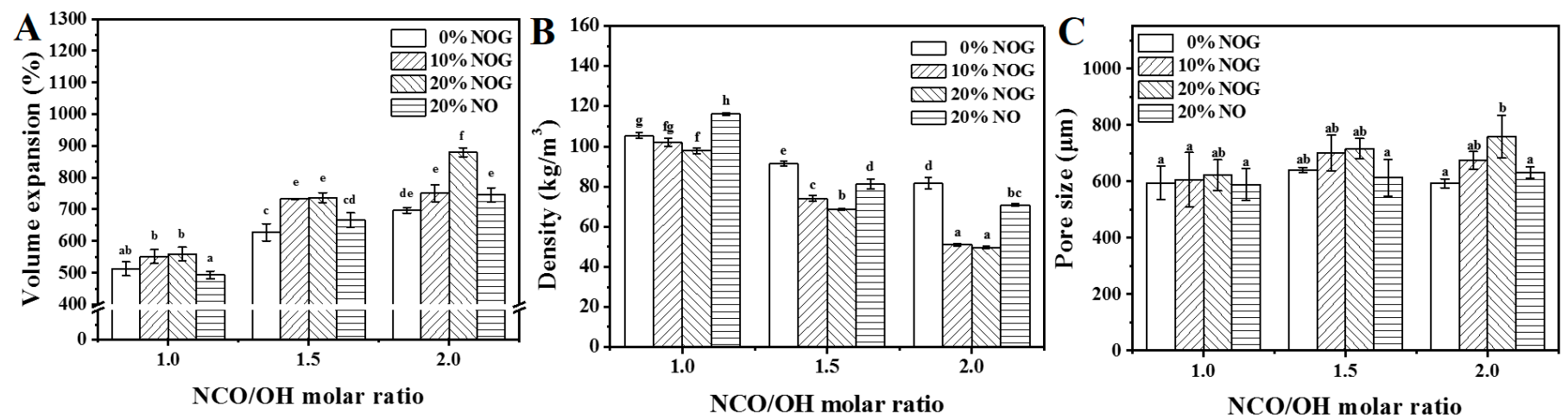

Figure 3. Volume expansion (A), density (B) and pore size (C) of PU foams. The NCO/OH molar ratios of O1-2, O2-2 and O3-2 set as 1.3, 1.9 and 2.5, respectively. The data analyzed using one-way ANOVA with Scheffe's test, the different lowercase letters indicate statistical differences in the bar graph. 


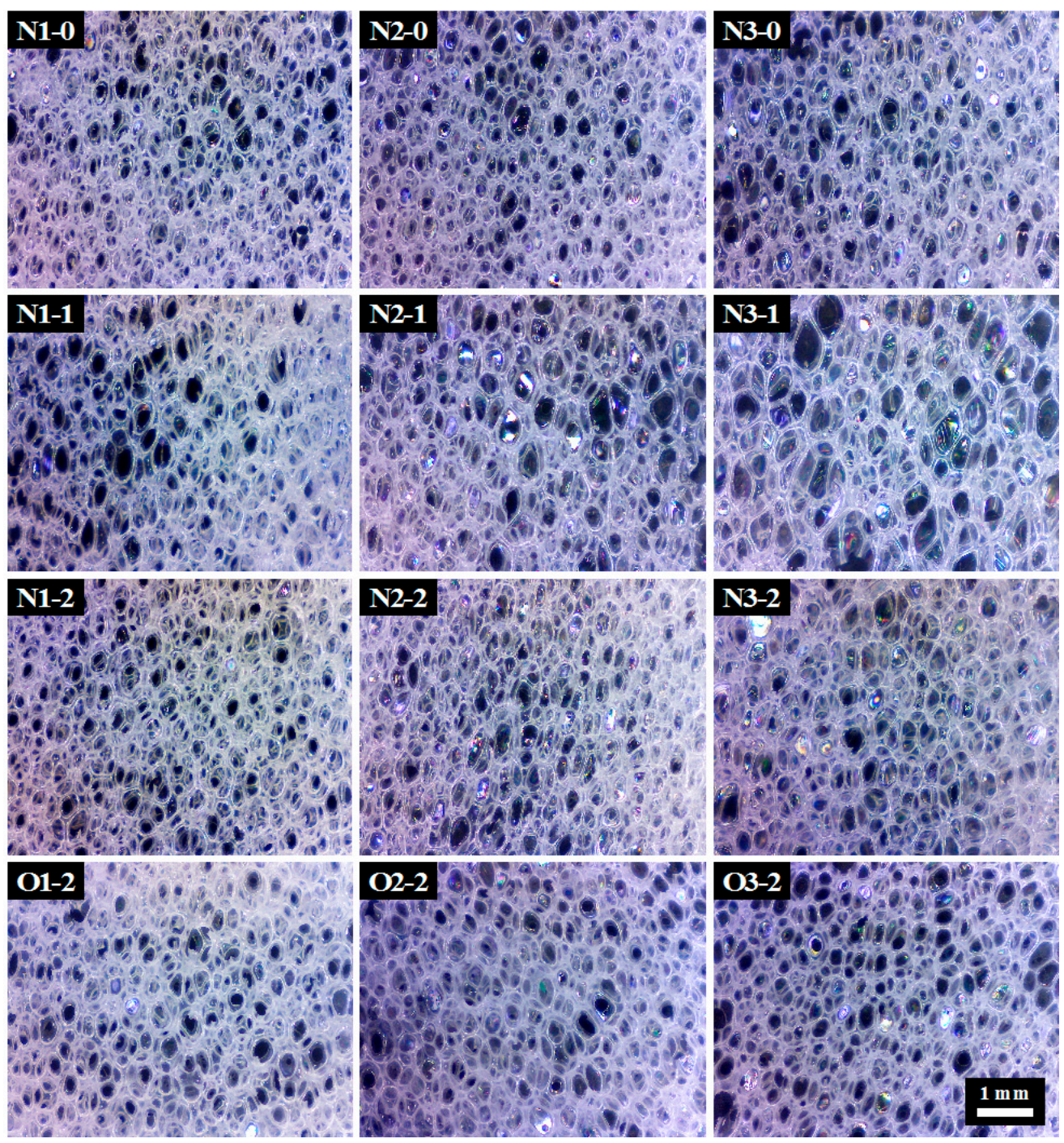

Figure 4. Pore micrographs of PU foams. All scale bars of subfigures are the same as O3-2.

\subsection{FTIR Spectra for PU Foams}

Figure 5 exhibits the FT-IR spectra of PU foams. NOG- and neem oil-based PU foams have a similar pattern as castor oil-based PU resin [12,23]. The region at 3330 $3380 \mathrm{~cm}^{-1}$ assigned to the $\mathrm{O}-\mathrm{H}$ and $\mathrm{N}-\mathrm{H}$ stretching vibration. The peaks at $2929 \mathrm{~cm}^{-1}$ and $2856 \mathrm{~cm}^{-1}$ are attributed the methyl and methylene groups, respectively. The $\mathrm{C}=\mathrm{O}$ stretching vibrations of free urethane, bonded urethane and bonded urea are ascribed to the peaks at 1743,1686 , and $1640 \mathrm{~cm}^{-1}$, respectively. The $\mathrm{N}-\mathrm{H}$ bending vibration and the C-N stretching vibration for amide II assigned to at $1523 \mathrm{~cm}^{-1}$. The absorption intensity at $1258 \mathrm{~cm}^{-1}$ can be attributed to amide III. Table 3 shows the relative absorption intensities of bonded urethane, bonded urea, amide II, and amide III to free urethane. The results indicated that the $\mathrm{NCO} / \mathrm{OH}$ ratio and $\mathrm{NOG}$ ratio increased with increasing ratios of amide II, amide III and bonded urea to free urethane. This can be attributed to a high $\mathrm{NCO} / \mathrm{OH}$ ratio resulting in an increase of hard segment content, which led to increased absorption intensity [35]. Furthermore, secondary hydroxyl groups of NOG polyol reacted with isocyanate which increased stiffness of chain reduces chain mobility and increasing hard segment content [34]. Although $\mathrm{NCO} / \mathrm{OH}$ ratios of $\mathrm{O} 1-2, \mathrm{O} 2-2$ and O3-2 are higher than that of N1-2, N2-2 and N3-2, the result indicated that adding neem oil reduces the relative absorption intensities of urea, amide II, amide III and urethane because of the dilution of PU resin. The FT-IR spectra data demonstrated that increasing the NCO/OH and NOG ratios could affect the structure of PU resins. 

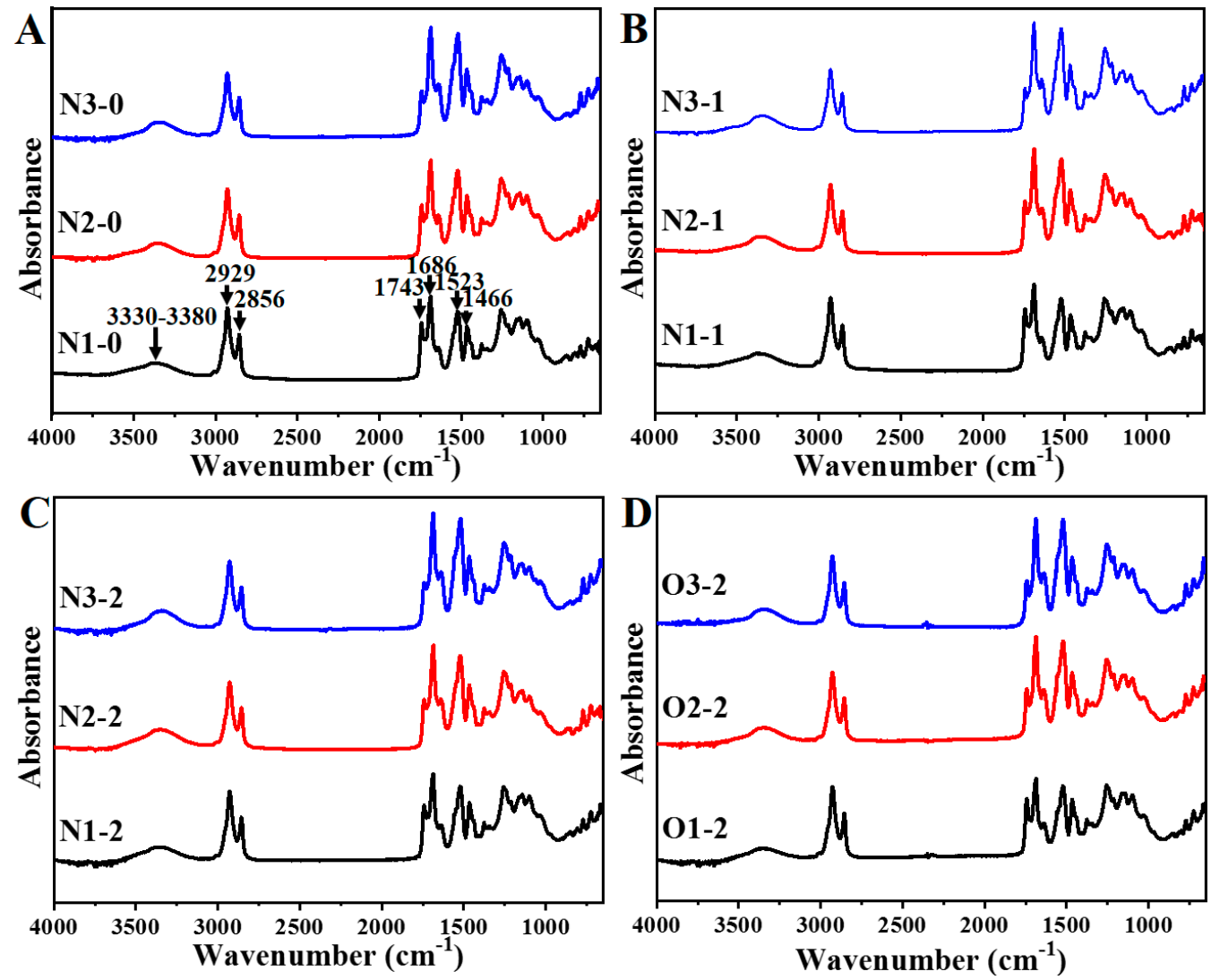

Figure 5. FT-IR spectra of 0\% NOG (A), 10\% NOG (B), 20\% NOG (C) and 20\% neem oil (D).

Table 3. Relative intensity of bonded urethane, bonded urea, amide II and amide III to free urethane.

\begin{tabular}{|c|c|c|c|c|}
\hline \multirow{2}{*}{ Code } & \multicolumn{4}{|c|}{ Relative Absorption Intensity * } \\
\hline & $\begin{array}{l}\text { Bonded Urethane } \\
\left(1686 \mathrm{~cm}^{-1}\right)\end{array}$ & $\begin{array}{l}\text { Bonded Urea } \\
\left(1640 \mathrm{~cm}^{-1}\right)\end{array}$ & $\begin{array}{c}\text { Amide II } \\
\left(1523 \mathrm{~cm}^{-1}\right)\end{array}$ & $\begin{array}{c}\text { Amide III } \\
\left(1258 \mathrm{~cm}^{-1}\right)\end{array}$ \\
\hline N1-0 & 1.75 & 0.30 & 1.32 & 1.37 \\
\hline N1-1 & 1.74 & 0.84 & 1.57 & 1.43 \\
\hline N1-2 & 2.32 & 1.15 & 2.19 & 1.75 \\
\hline N2-0 & 1.55 & 0.35 & 1.23 & 1.23 \\
\hline N2-1 & 2.03 & 0.87 & 1.83 & 1.53 \\
\hline N2-2 & 2.42 & 1.20 & 2.29 & 1.85 \\
\hline N3-0 & 1.54 & 0.66 & 1.32 & 1.32 \\
\hline N3-1 & 2.07 & 1.01 & 1.86 & 1.55 \\
\hline N3-2 & 2.40 & 1.21 & 2.28 & 1.80 \\
\hline O1-2 & 1.28 & 0.66 & 1.17 & 1.19 \\
\hline $\mathrm{O} 2-2$ & 1.84 & 0.98 & 1.76 & 1.47 \\
\hline O3-2 & 1.81 & 1.10 & 1.81 & 1.48 \\
\hline
\end{tabular}

* Based on the absorption intensity of the free urethane bond at $1743 \mathrm{~cm}^{-1}$.

\subsection{Mechanical Properties of PU Foams}

The upward growth direction of the PU foam during the foaming process is defined as the vertical direction. Figure 6 shows the mechanical properties in the vertical and parallel directions. The results indicated that compressive strengths at $10 \%$ and $25 \%$ strain and young's modulus of vertical direction were slightly higher than those of the parallel direction. The result indicates that PU foams have anisotropy because the pores of PU foam elongated slightly in the foaming direction (Figure 4), which enhances the mechanical properties of PU foam in the vertical direction [36]. The specific compressive strength 
was determined as the compressive strength divided by PU foam density to normalize the mechanical properties [37,38]. Figure 7 shows the specific compressive strengths of the PU foams. The ranges of specific compressive strengths of PU foams were from 0.0082 to $0.0795 \mathrm{kPa} \cdot \mathrm{m}^{3} / \mathrm{kg}$ and 0.0056 to $0.0704 \mathrm{kPa} \cdot \mathrm{m}^{3} / \mathrm{kg}$ in the vertical and parallel directions, respectively. In previous studies, the specific compressive strength of PU foams reinforced with organic filler ranged from 0.0049 to $0.0073 \mathrm{kPa} \cdot \mathrm{m}^{3} / \mathrm{kg}[39,40]$. The specific compressive strengths of the bio-based PU foams were much higher than those of PU foams in previous studies [37]. When the $\mathrm{NCO} / \mathrm{OH}$ ratios were set at 1.0 and 1.5 , the results indicated that the specific compressive strength at $10 \%$ strain had no significant difference. In contrast, increasing the NOG ratio can increase the specific compressive strength at $25 \%$ strain. When that $\mathrm{NCO} / \mathrm{OH}$ ratio was set as 2.0 , increasing the $\mathrm{NCO} / \mathrm{OH}$ ratios and neem oil can significantly increase the specific compressive strength at $25 \%$ strain. The results showed that specific compressive strength increases as polyol reacts with a twice-molar ratio of the isocyanate. This is because a high $\mathrm{NCO} / \mathrm{OH}$ ratio increases the crosslinking and hard segment domain [41]. On the other hand, NOG can help react with isocyanate to increase the stiffness of the chain and improve the specific compressive strength in a low $\mathrm{NCO} / \mathrm{OH}$ ratio [34]. The specific compressive strength at $25 \%$ strain of $\mathrm{O} 2-2$ is higher than that of N3-2 at NCO/OH ratio of ca. 2.0. The result indicates that neem oil can also help to enhance the specific compressive strength. The addition of $5 \%$ linseed oil can also improve slightly compressive strength. The results suggest that the fatty acid chain can be a natural modifier and help protect the structure against compressive stress [20]. The results demonstrate that NOG and neem oil can enhance the mechanical properties of PU foams.
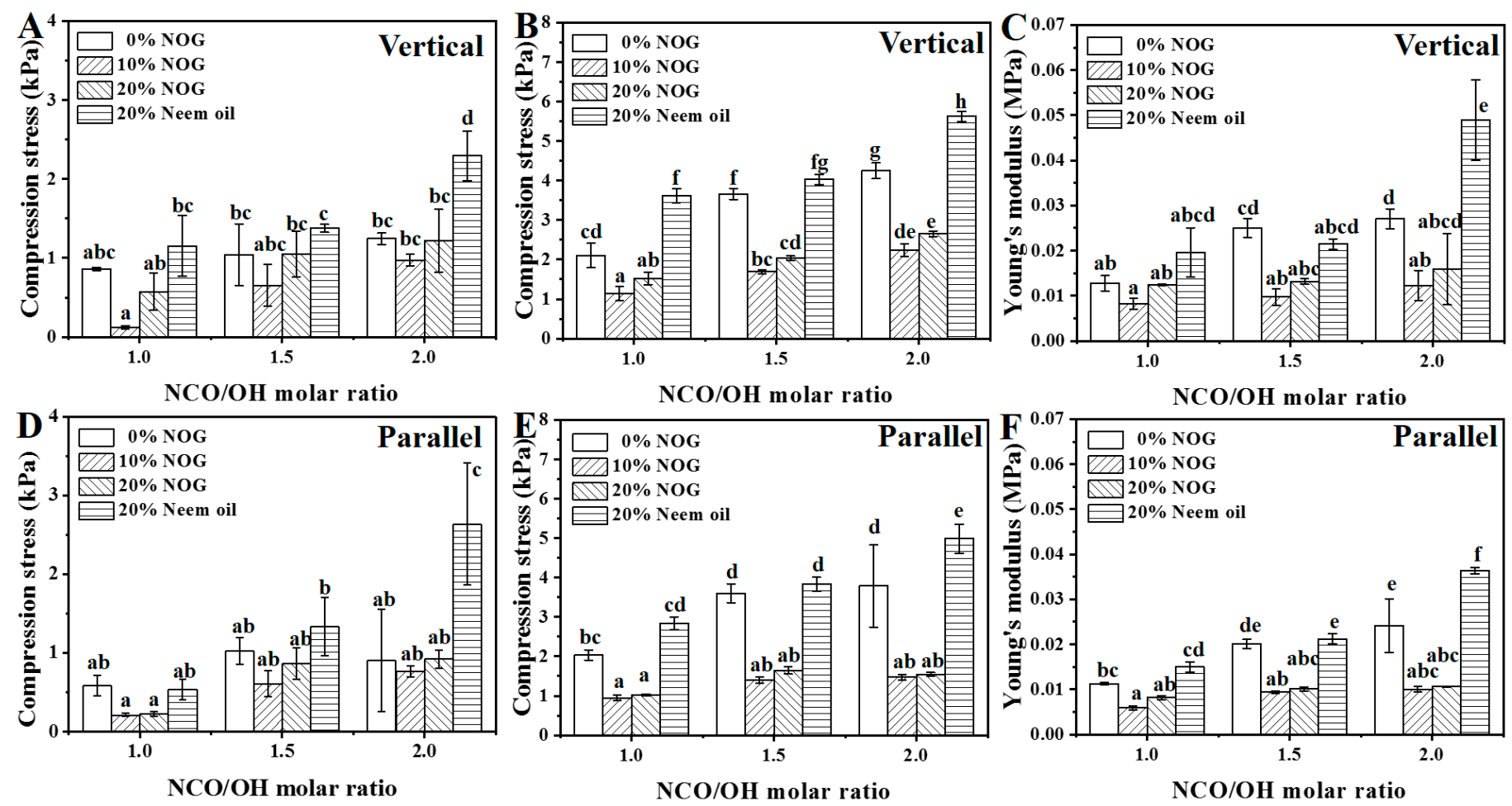

Figure 6. Compressive strength at $10 \%(\mathbf{A}, \mathbf{D})$ and $25 \%(\mathbf{B}, \mathbf{E})$ strain and young's modulus $(\mathbf{C}, \mathbf{F})$ in the vertical and parallel directions. The NCO/OH molar ratios of O1-2, O2-2 and O3-2 set as 1.3, 1.9 and 2.5, respectively. The data analyzed using one-way ANOVA with Scheffe's test, the different lowercase letters indicate statistical differences in the bar graph. 

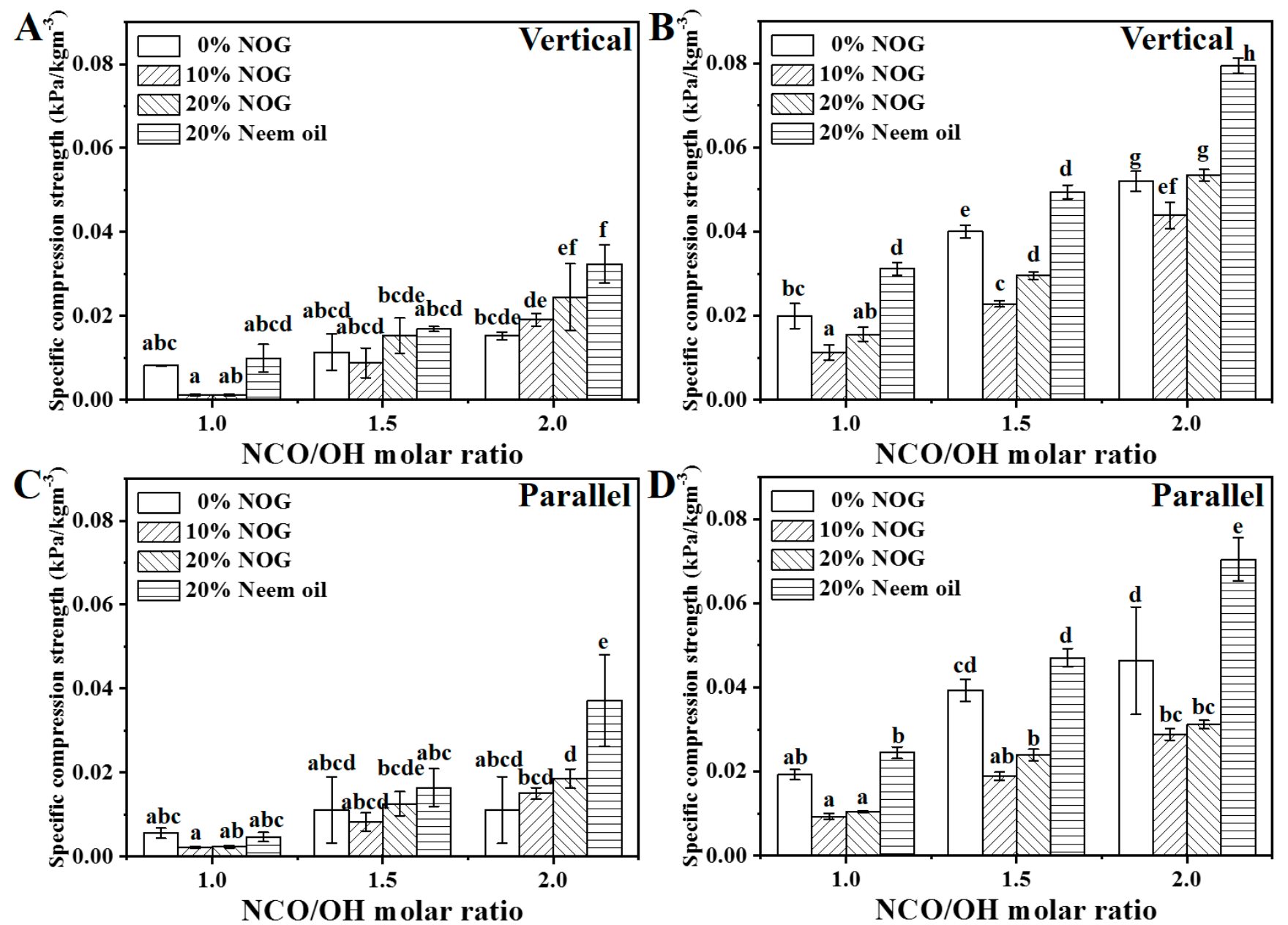

Figure 7. Specific compressive strength at $10 \%(\mathbf{A}, \mathbf{C})$ and $25 \%(\mathbf{B}, \mathbf{D})$ strain in the vertical and parallel directions. The $\mathrm{NCO} / \mathrm{OH}$ molar ratios of O1-2, O2-2 and O3-2 set as 1.3, 1.9 and 2.5, respectively. The data analyzed using one-way ANOVA with Scheffe's test, the different lowercase letters indicate statistical differences in the bar graph.

\subsection{Water and Solvents Resistance of PU Foams}

The weight retentions for PU foams in water, acetone and ethyl acetate are listed in Figure 8 . The weight retentions are ca. $100 \%$ in water (Figure $8 \mathrm{~A}, \mathrm{~B}$ ). The results indicate that the bio-based PU foams are waterproof and can be used as commodities. In acetone and ethyl acetate, the weight retentions of PU foams are $79.4-97.6 \%$ and $79.0-97.7 \%$, respectively (Figure 8 C,D). The results indicate that PU foams with a higher molar ratio of $\mathrm{NCO} / \mathrm{OH}$ were more resistant to organic solvent because of the high degree of crosslinking. $\mathrm{NCO} / \mathrm{OH}$ ratios of O1-2, O2-2 and O3-2 are higher than that of N1-2, N2-2 and N3-2, solvents resistance of neem oil-based PU foams are lower than those of NOG-based PU foams. Notably, increasing the NOG ratio enhanced the solvent resistance significantly. The results suggested that the crosslinking density of the NOG-based PU foam was higher than castor oil-based and neem oil-based $\mathrm{PU}$ foams when that $\mathrm{NCO} / \mathrm{OH}$ ratio set higher than 1.5. The solvents resistance of neem oil-based PU foams was significantly lower than those of NOG-based PU foams. This is because neem oil has no reactive hydroxyl group, which reduces the structure of urethane, urea, amide II and, amide III (Table 3). The previous study also indicated polyol with secondary hydroxyl groups can increase the crosslinking density of PU resin [34]. The results demonstrate that NOG can enhance the solvent resistance of bio-based PU foam. 

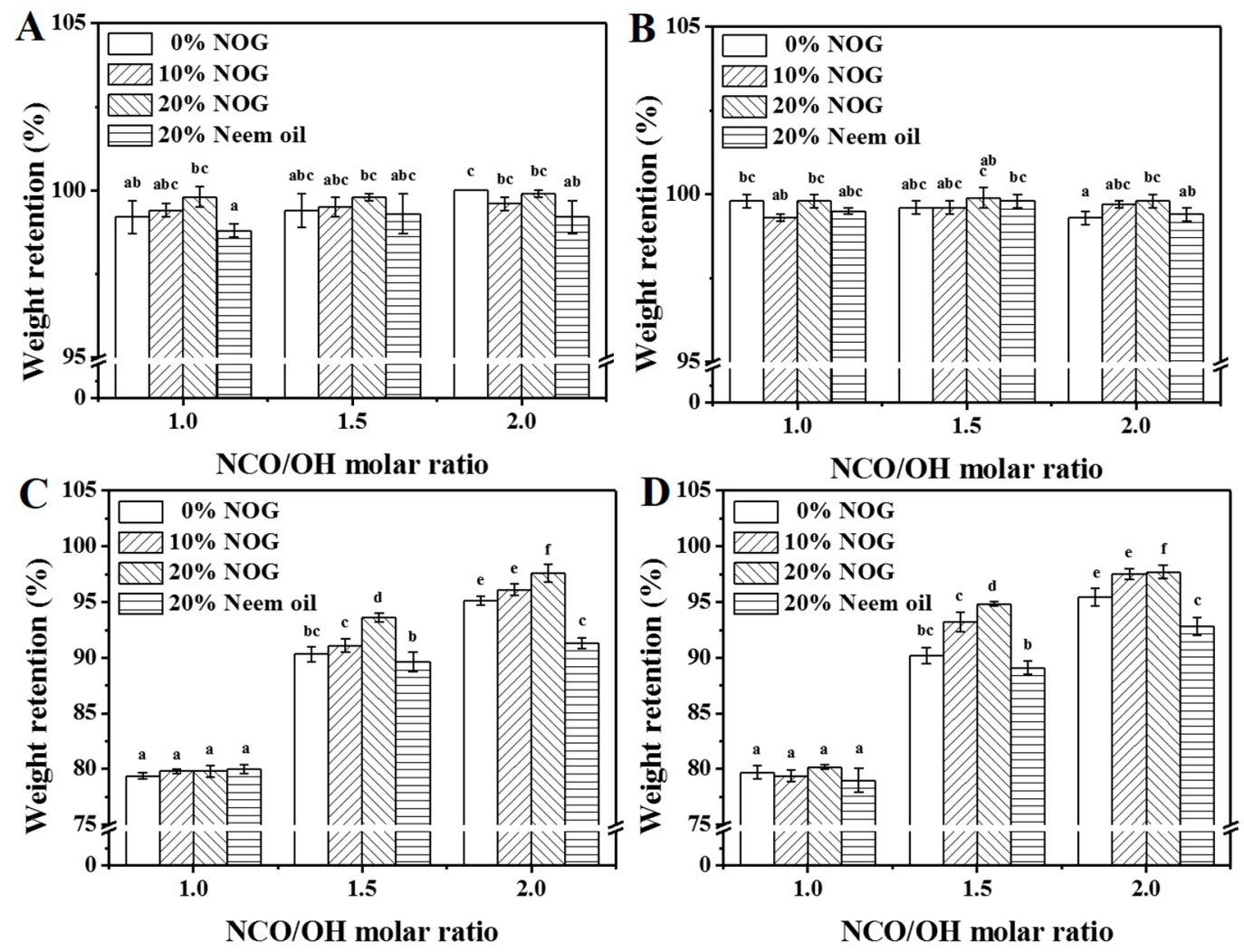

Figure 8. The weight retention of $\mathrm{PU}$ foams immersed in $25{ }^{\circ} \mathrm{C}(\mathbf{A})$ and $50{ }^{\circ} \mathrm{C}(\mathbf{B})$ distilled water, acetone (C) and ethyl acetate (D) for $1 \mathrm{~h}$. The NCO/OH molar ratios of O1-2, O2-2 and O3-2 set as 1.3, 1.9 and 2.5, respectively. The data analyzed using one-way ANOVA with Scheffe's test, the different lowercase letters indicate statistical differ-ences in the bar graph.

\subsection{Thermal Properties of PU Foams}

Figure 9 exhibits the TG curves and differential TG (DTG) curves of PU foams. According to the DTG curves, PU foams' thermal decomposition can be divided into two or three thermal decomposition stages. Multiple decomposition steps occurred in PU polymers, similar to previous studies [12,23]. The thermal decomposition temperature occurred between 250 to $400{ }^{\circ} \mathrm{C}$ and presented multiple thermal patterns. The decomposition can be attributed to the degradation of the hard segment, including urea, urethane, biuret and allophanate structures [42]. The results show that increasing the $\mathrm{NCO} / \mathrm{OH}$ molar ratio changed the thermal degradation from three stages to two stages and the onset temperature increased. Increasing the $\mathrm{NCO} / \mathrm{OH}$ ratio led to formation of more urea structure and increased the intermolecular force between PU polymer chains (Table 3). At I stage, Table 4 shows the weight loss at high $\mathrm{NCO} / \mathrm{OH}$ ratio is higher than that at low $\mathrm{NCO} / \mathrm{OH}$ ratio. Increasing $\mathrm{NCO} / \mathrm{OH}$ ratio also caused a side reaction and formed allophanate and biuret structures, which reduces the thermal stability and increased thermal weight loss [43]. A previous study indicated the TGA results for castor oil [44]. The result indicated that the temperature range of mass loss is around 300 to $420^{\circ} \mathrm{C}$. The thermal decomposition between 400 to $550^{\circ} \mathrm{C}$ can be attributed to the degradation of the soft segments of castor and neem oils [23]. The results show that high $\mathrm{NCO} / \mathrm{OH}$ ratio at synthesis of the foams causes low weight loss at stage II because the proportion of soft segments in PU decreases. The temperatures of neem oil- and NOG-based PU foams at $10 \%\left(\mathrm{~T}_{10}\right)$ weight loss ranged from 283 to $290^{\circ} \mathrm{C}$. These results the PU foams had similar thermal stability. $\mathrm{T}_{10}$ of castor oil glyceride-based $\mathrm{PU}$ resin and $\mathrm{TiO}_{2}$ were ca. $250{ }^{\circ} \mathrm{C}$ in the previous study [45]. The results indicate that mixing NOG and neem oil with castor oil-based PU foams have good thermal stability because of the secondary hydroxyl groups and the oil-based soft segments [23,34]. 

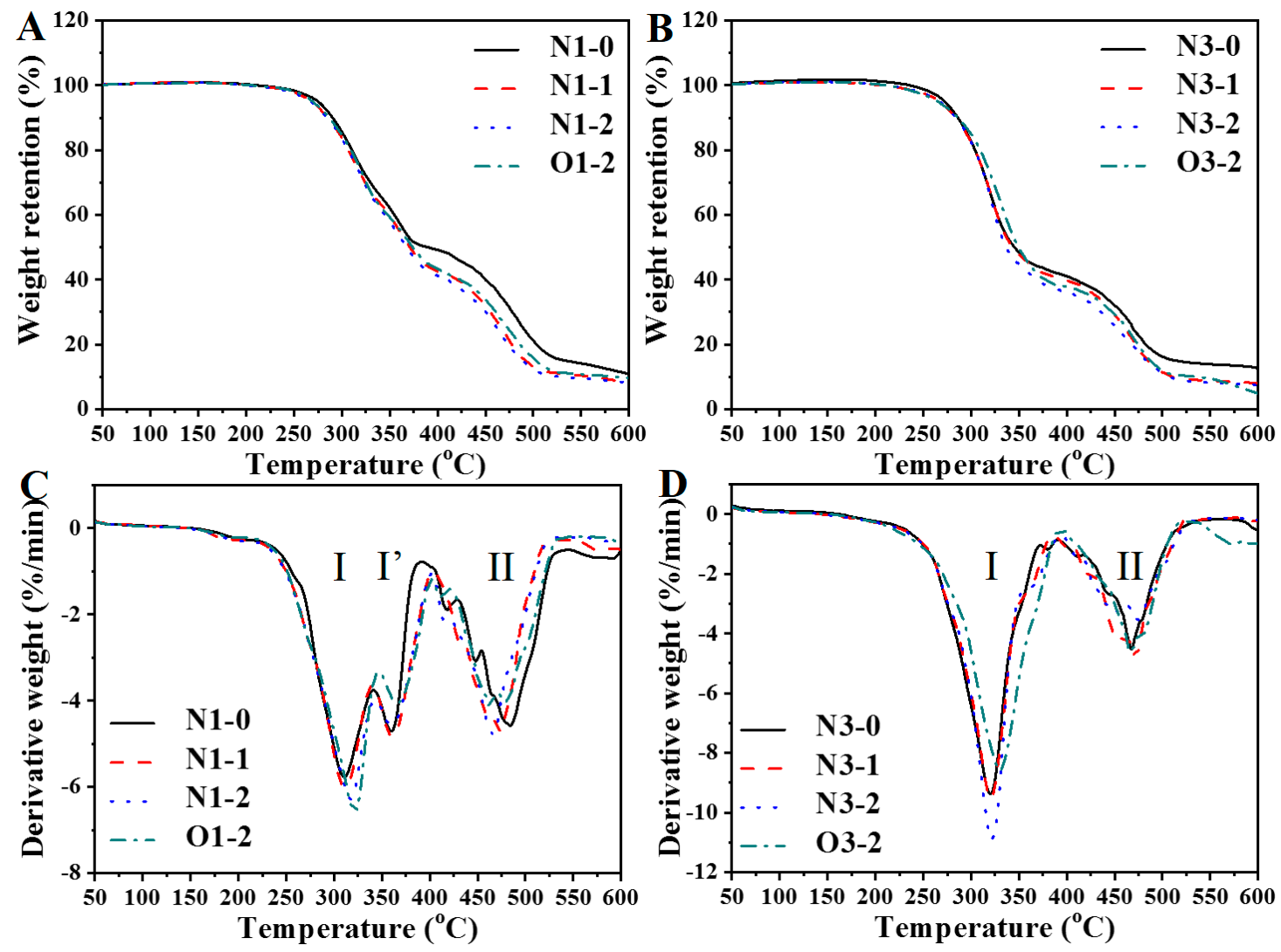

Figure 9. TGA (A,B) and DTG (C,D) curves for PU foams.

Table 4. Thermal parameters of PU foams.

\begin{tabular}{|c|c|c|c|c|c|c|c|c|c|c|c|c|c|c|}
\hline \multirow{3}{*}{ Code } & \multicolumn{4}{|c|}{ I } & \multicolumn{4}{|c|}{$\mathbf{I}^{\prime}$} & \multicolumn{4}{|c|}{ II } & \multirow{3}{*}{$\begin{array}{l}\mathrm{T}_{10}{ }^{3} \\
\left({ }^{\circ} \mathrm{C}\right)\end{array}$} & \multirow{3}{*}{$\begin{array}{c}\text { Char Yield }{ }^{4} \\
(\%)\end{array}$} \\
\hline & Onset & Peak & $W L^{1}$ & $\mathbf{P H}^{2}$ & Onset & Peak & WL & PH & Onset & Peak & WL & PH & & \\
\hline & $\left({ }^{\circ} \mathrm{C}\right)$ & $\left({ }^{\circ} \mathrm{C}\right)$ & $(\%)$ & $(\% / \min )$ & $\left({ }^{\circ} \mathrm{C}\right)$ & $\left({ }^{\circ} \mathrm{C}\right)$ & $(\%)$ & $(\% / \min )$ & $\left({ }^{\circ} \mathrm{C}\right)$ & $\left({ }^{\circ} \mathrm{C}\right)$ & $(\%)$ & $(\% / \mathrm{min})$ & & \\
\hline N1-0 & 275 & 310 & 36.6 & 5.8 & 355 & 360 & 17.1 & 4.7 & 445 & 484 & 26.2 & 4.6 & 290 & 10.9 \\
\hline N1-1 & 267 & 312 & 38.7 & 6.0 & 350 & 361 & 20.0 & 4.8 & 432 & 474 & 27.7 & 4.7 & 285 & 8.2 \\
\hline N1-2 & 272 & 318 & 43.2 & 6.3 & 351 & 360 & 22.2 & 4.6 & 433 & 466 & 24.8 & 4.8 & 284 & 8.1 \\
\hline O1-2 & 273 & 321 & 41.1 & 6.6 & 358 & 366 & 18.1 & 4.1 & 436 & 463 & 26.5 & 4.2 & 286 & 9.6 \\
\hline N3-0 & 278 & 320 & 61.2 & 9.4 & - & - & - & - & 432 & 468 & 21.9 & 4.5 & 286 & 12.7 \\
\hline N3-1 & 281 & 321 & 60.3 & 9.6 & - & - & - & - & 430 & 473 & 21.9 & 4.8 & 286 & 8.0 \\
\hline N3-2 & 285 & 322 & 60.6 & 10.9 & - & - & - & - & 423 & 474 & 27.1 & 3.6 & 283 & 7.4 \\
\hline $\mathrm{O} 3-2$ & 293 & 330 & 57.3 & 8.5 & - & - & - & - & 430 & 467 & 25.0 & 4.5 & 286 & 4.9 \\
\hline
\end{tabular}

${ }^{1}$ WL: Weight loss. ${ }^{2}$ PH: Peak height. ${ }^{3} \mathrm{~T}_{10}$ : Temperature at $10 \%$ weight loss occurs. ${ }^{4}$ Char yield: Char yield at $600{ }^{\circ} \mathrm{C}$.

\section{Conclusions}

In this study, castor oil-based PU foams were modified by neem oil and NOG. Castor oil and NOG were used as bio-polyol and Desmodur N with NCO/OH molar ratios of 1.0, 1.5 and 2.0. NOG is a narrow-distribution polyol. The average hydroxyl content of NOG was higher than that of castor oil and neem oil. The short and controllable reaction time of PU foam can be accepted in manufacturing processes. The results show that the end of rising time and tack-free time of NOG-based PU foams can be reduced significantly. NOGmodified PU foams show low density and excellent organic solvent resistance. In contrast, adding neem oil increases the density and mechanical properties but reduces the chemical resistance of $\mathrm{PU}$ foam. The mechanical properties of $\mathrm{PU}$ foams were reinforced with addition of NOG or neem oil at $\mathrm{NCO} / \mathrm{OH}$ ratios of 1.0 to 1.5. Adding $\mathrm{NOG}$ and $\mathrm{NCO} / \mathrm{OH}$ ratio affect the chemical structure and increase the hard segment content, resulting in enhanced mechanical properties. Increasing the $\mathrm{NCO} / \mathrm{OH}$ molar ratio led to high weight 
retention in the chemical solvent resistance, indicating a better cross-linked structure. The TG analysis results show that NOG-based PU foams' thermal stabilities are slightly lower than those of neem oil-based foams. All PU foams have excellent thermal stability. This result demonstrates that bio-based $\mathrm{PU}$ foams can be prepared with various properties by adjusting the molar ratios of $\mathrm{NCO} / \mathrm{OH}, \mathrm{NOG}$ and neem oil. Neem oil and its glyceride can act a nature modifier and bio-based polyol. The PU resins can be used as cushion foam [46] and a wood composite adhesive [12]. This investigation demonstrated the feasibility of the application of non-edible oils in the bio-based PU industrial process in the near future.

Author Contributions: Conceptualization, Y.-C.C.; methodology, Y.-H.L., Y.-L.S. and Y.-C.C.; software, Y.-H.L., Y.-L.S. and Y.-C.C.; validation, Y.-H.L. and Y.-C.C.; investigation, Y.-H.L., Y.-L.S. and Y.-C.C.; resources, Y.-C.C.; writing-original draft preparation, Y.-H.L. and Y.-L.S.; writing-review and editing, Y.-C.C.; supervision, Y.-C.C.; funding acquisition, Y.-C.C. All authors have read and agreed to the published version of the manuscript.

Funding: This research was funded by Ministry of Science and Technology of Taiwan (ROC), grant number 107-2311-B-005-010-MY3, ENABLE (ENgineering in Agriculture Biotech LEadership) Center of National Chung-Hsing University, grant number 110ST001B and Council of Agriculture, Executive Yuan (Taiwan), grant number 110AS-17.1.2-ST-a3.

Institutional Review Board Statement: Not applicable.

Informed Consent Statement: Not applicable.

Data Availability Statement: The data presented in this study are available on request from the corresponding author.

Acknowledgments: The authors sincerely thank Wen-Jau Lee (Department of Forestry, National Chung Hsing University) for experimental support.

Conflicts of Interest: The authors declare no conflict of interest.

\section{References}

1. Vale, M.; Mateus, M.M.; Galhano dos Santos, R.; Nieto de Castro, C.; de Schrijver, A.; Bordado, J.C.; Marques, A.C. Replacement of petroleum-derived diols by sustainable biopolyols in one component polyurethane foams. J. Clean. Prod. 2019, 212, $1036-1043$. [CrossRef]

2. $\quad$ Engels, H.W.; Pirkl, H.G.; Albers, R.; Albach, R.W.; Krause, J.; Hoffmann, A.; Casselmann, H.; Dormish, J. Polyurethanes: Versatile materials and sustainable problem solvers for today's challenges. Angew. Chem. Int. Ed. 2013, 52, 9422-9441. [CrossRef]

3. Agrawal, A.; Kaur, R.; Walia, R.S. PU foam derived from renewable sources: Perspective on properties enhancement: An overview. Eur. Polym. J. 2017, 95, 255-274. [CrossRef]

4. Hejna, A.; Kirpluks, M.; Kosmela, P.; Cabulis, U.; Haponiuk, J.; Piszczyk, Ł. The influence of crude glycerol and castor oil-based polyol on the structure and performance of rigid polyurethane-polyisocyanurate foams. Ind. Crop. Prod. 2017, 95, 113-125. [CrossRef]

5. Kurańska, M.; Prociak, A. The influence of rapeseed oil-based polyols on the foaming process of rigid polyurethane foams. Ind. Crop. Prod. 2016, 89, 182-187. [CrossRef]

6. Liang, H.; Wang, S.; He, H.; Wang, M.; Liu, L.; Lu, J.; Zhang, Y.; Zhang, C. Aqueous anionic polyurethane dispersions from castor oil. Ind. Crop. Prod. 2018, 122, 182-189. [CrossRef]

7. Yousuf, A. Biodiesel from lignocellulosic biomass-Prospects and challenges. Waste Manag. 2012, 32, 2061-2067. [CrossRef]

8. Ashraful, A.M.; Masjuki, H.H.; Kalam, M.A.; Rizwanul Fattah, I.M.; Imtenan, S.; Shahir, S.A.; Mobarak, H.M. Production and comparison of fuel properties, engine performance, and emission characteristics of biodiesel from various non-edible vegetable oils: A review. Energy Convers. Manag. 2014, 80, 202-228. [CrossRef]

9. Saha, P.; Khomlaem, C.; Aloui, H.; Kim, B.S. Biodegradable polyurethanes based on castor oil and poly (3-hydroxybutyrate). Polymers 2021, 13, 1387. [CrossRef]

10. Borrero-López, A.M.; Valencia, C.; Blánquez, A.; Hernández, M.; Eugenio, M.E.; Franco, J.M. Cellulose pulp- and castor oil-based polyurethanes for lubricating applications: Influence of streptomyces action on barley and wheat straws. Polymers 2020, $12,2822$. [CrossRef] [PubMed]

11. Gurunathan, T.; Mohanty, S.; Nayak, S.K. Isocyanate terminated castor oil-based polyurethane prepolymer: Synthesis and characterization. Prog. Org. Coat. 2015, 80, 39-48. [CrossRef]

12. Chen, Y.C.; Tai, W. Castor oil-based polyurethane resin for low-density composites with bamboo charcoal. Polymers 2018, 10, 1100. [CrossRef] [PubMed]

13. Ogunniyi, D.S. Castor oil: A vital industrial raw material. Bioresour. Technol. 2006, 97, 1086-1091. [CrossRef] [PubMed] 
14. Lee, J.H.; Kim, S.H.; Oh, K.W. Bio-based polyurethane foams with castor oil based multifunctional polyols for improved compressive properties. Polymers 2021, 13, 576. [CrossRef] [PubMed]

15. Mutlu, H.; Meier, M.A.R. Castor oil as a renewable resource for the chemical industry. Eur. J. Lipid Sci. Technol. 2010, 112, 10-30. [CrossRef]

16. Chaudhari, A.B.; Anand, A.; Rajput, S.D.; Kulkarni, R.D.; Gite, V.V. Synthesis, characterization and application of azadirachta indica juss (neem oil) fatty amides (aijfa) based polyurethanes coatings: A renewable novel approach. Prog. Org. Coat. 2013, 76, 1779-1785. [CrossRef]

17. Chaudhari, A.; Gite, V.; Rajput, S.; Mahulikar, P.; Kulkarni, R. Development of eco-friendly polyurethane coatings based on neem oil polyetheramide. Ind. Crop. Prod. 2013, 50, 550-556. [CrossRef]

18. Marathe, R.; Tatiya, P.; Chaudhari, A.; Lee, J.; Mahulikar, P.; Sohn, D.; Gite, V. Neem acetylated polyester polyol—renewable source based smart pu coatings containing quinoline (corrosion inhibitor) encapsulated polyurea microcapsules for enhance anticorrosive property. Ind. Crop. Prod. 2015, 77, 239-250. [CrossRef]

19. Das, P.; Sharma, N.; Puzari, A.; Kakati, D.K.; Devi, N. Synthesis and characterization of neem (azadirachta indica) seed oil-based alkyd resins for efficient anticorrosive coating application. Polym. Bull. 2021, 78, 457-479. [CrossRef]

20. Członka, S.; Bertino, M.F.; Kośny, J.; Strąkowska, A.; Masłowski, M.; Strzelec, K. Linseed oil as a natural modifier of rigid polyurethane foams. Ind. Crop. Prod. 2018, 115, 40-51. [CrossRef]

21. Mehta, P.S.; Mehta, A.S.; Mehta, S.J.; Makhijani, A.B. Bhopal tragedy's health effects: A review of methyl isocyanate toxicity. JAMA 1990, 264, 2781-2787. [CrossRef]

22. Salmon, A.G.; Kerr Muir, M.; Andersson, N. Acute toxicity of methyl isocyanate: A preliminary study of the dose response for eye and other effects. Br. J. Ind. Med. 1985, 42, 795-798. [CrossRef]

23. Hsieh, C.C.; Chen, Y.C. Synthesis of bio-based polyurethane foam modified with rosin using an environmentally-friendly process. J. Clean. Prod 2020, 276, 124203. [CrossRef]

24. Chaudhari, A.; Kulkarni, R.; Mahulikar, P.; Sohn, D.; Gite, V. Development of PU coatings from neem oil based alkyds prepared by the monoglyceride route. J. Am. Oil Chem. Soc. 2015, 92, 733-741. [CrossRef]

25. Lee, W.J.; Yu, C.Y.; Chen, Y.C. Preparation and characteristics of polyurethane made with polyhydric alcohol-liquefied rice husk. J. Appl. Polym. Sci. 2018, 135, 45910. [CrossRef]

26. Zhang, Y.; Yan, R.; Ngo, T.-d.; Zhao, Q.; Duan, J.; Du, X.; Wang, Y.; Liu, B.; Sun, Z.; Hu, W.; et al. Ozone oxidized lignin-based polyurethane with improved properties. Eur. Polym. J. 2019, 117, 114-122. [CrossRef]

27. Harikrishnan, G.; Khakhar, D.V. Effect of monomer temperature on foaming and properties of flexible polyurethane foams. $J$. Appl. Polym. Sci. 2007, 105, 3439-3443. [CrossRef]

28. Choe, E.; Min, D.B. Mechanisms and factors for edible oil oxidation. Compr. Rev. Food Sci. Food Saf. 2006, 5, 169-186. [CrossRef]

29. Chang, C.W.; Lu, K.T. Linseed-oil-based waterborne uv/air dual-cured wood coatings. Prog. Org. Coat. 2013, 76, 1024-1031. [CrossRef]

30. Zhou, W.; Jia, P.; Zhou, Y.; Zhang, M. Preparation and characterization of tung oil-based flame retardant polyols. Chin. J. Chem. Eng. 2018, 26, 2664-2671. [CrossRef]

31. Allauddin, S.; Narayan, R.; Raju, K.V.S.N. Synthesis and properties of alkoxysilane castor oil and their polyurethane/urea-silica hybrid coating films. Acs Sustain. Chem. Eng. 2013, 1, 910-918. [CrossRef]

32. Zhang, J.; Hori, N.; Takemura, A. Influence of NCO/OH ratio on preparation of four agricultural wastes liquefied polyols based polyurethane foams. Polym. Degrad. Stab. 2020, 179, 109256. [CrossRef]

33. Silva, B.B.R.; Santana, R.M.C.; Forte, M.M.C. A solventless castor oil-based PU adhesive for wood and foam substrates. Int. J. Adhes. Adhes. 2010, 30, 559-565. [CrossRef]

34. Tilly, J.C.; Pervaje, A.K.; Inglefield, D.L.; Santiso, E.E.; Spontak, R.J.; Khan, S.A. Spectroscopic and rheological cross-analysis of polyester polyol cure behavior: Role of polyester secondary hydroxyl content. ACS Omega 2019, 4, 932-939. [CrossRef] [PubMed]

35. Lin, W.T.; Lee, W.J. Effects of the NCO/OH molar ratio and the silica contained on the properties of waterborne polyurethane resins. Colloids Surf. Phys. Eng. Asp. 2017, 522, 453-460. [CrossRef]

36. Hamilton, A.R.; Thomsen, O.T.; Madaleno, L.A.O.; Jensen, L.R.; Rauhe, J.C.M.; Pyrz, R. Evaluation of the anisotropic mechanical properties of reinforced polyurethane foams. Compos. Sci. Technol. 2013, 87, 210-217. [CrossRef]

37. Gómez-Fernández, S.; Ugarte, L.; Calvo-Correas, T.; Peña-Rodríguez, C.; Corcuera, M.A.; Eceiza, A. Properties of flexible polyurethane foams containing isocyanate functionalized kraft lignin. Ind. Crop. Prod. 2017, 100, 51-64. [CrossRef]

38. Dolomanova, V.; Rauhe, J.C.M.; Jensen, L.R.; Pyrz, R.; Timmons, A.B. Mechanical properties and morphology of nano-reinforced rigid pu foam. J. Cell. Plast. 2011, 47, 81-93. [CrossRef]

39. Septevani, A.A.; Evans, D.A.C.; Martin, D.J.; Annamalai, P.K. Hybrid polyether-palm oil polyester polyol based rigid polyurethane foam reinforced with cellulose nanocrystal. Ind. Crop. Prod. 2018, 112, 378-388. [CrossRef]

40. Caglayan, C.; Osken, I.; Ataalp, A.; Turkmen, H.S.; Cebeci, H. Impact response of shear thickening fluid filled polyurethane foam core sandwich composites. Compos. Struct. 2020, 243, 112171. [CrossRef]

41. Wadekar, M.; Eevers, W.; Vendamme, R. Influencing the properties of ligninPU films by changing copolyol chain length, lignin content and nco/oh mol ratio. Ind. Crop. Prod. 2019, 141, 111655. [CrossRef]

42. Chattopadhyay, D.K.; Webster, D.C. Thermal stability and flame retardancy of polyurethanes. Prog. Polym. Sci. 2009, 34, 1068-1133. [CrossRef] 
43. Dutta, S.; Karak, N. Effect of the NCO/OH ratio on the properties of mesua ferrea l. Seed oil-modified polyurethane resins. Polym. Int. 2006, 55, 49-56. [CrossRef]

44. Ferreira, P.; Pereira, R.; Coelho, J.F.J.; Silva, A.F.M.; Gil, M.H. Modification of the biopolymer castor oil with free isocyanate groups to be applied as bioadhesive. Int. J. Biol. Macromol. 2007, 40, 144-152. [CrossRef] [PubMed]

45. Malik, M.; Kaur, R. Mechanical and thermal properties of castor oil-based polyurethane adhesive: Effect of TiO 2 filler. Adv. Polym. Tech. 2018, 37, 24-30. [CrossRef]

46. Gu, R.; Konar, S.; Sain, M. Preparation and characterization of sustainable polyurethane foams from soybean oils. J. Am. Oil Chem. Soc. 2012, 89, 2103-2111. [CrossRef] 